\title{
First record in South America of Didymosulcus palati and Didymosulcus philobranchiarca (Digenea, Didymozoidae) with new hosts records and pathological alterations
}

\author{
Márcia Cristina Nascimento Justo/ ${ }^{+}$, Rogério Tortelly ${ }^{1}$, Rodrigo Caldas Menezes², Anna Kohn \\ Laboratório de Helmintos Parasitos de Peixes, Instituto Oswaldo Cruz-Fiocruz, Av. Brasil 4365, 21045-900 Rio de Janeiro, RJ, Brasil ${ }^{1}$ De- \\ partamento de Patologia e Clínica, Faculdade de Veterinária, Universidade Federal Fluminense, Niterói, RJ, Brasil ${ }^{2}$ Serviço de Zoonoses, \\ Instituto de Pesquisa Clínica Evandro Chagas-Fiocruz, Rio de Janeiro, RJ, Brasil
}

Two species of Didymozoidae, Didymosulcus palati (Yamaguti 1970) and Didymosulcus philobranchiarca (Yamaguti 1970) were reported for the first time in South America, Atlantic Ocean, parasitizing three different tuna species from the coast of Rio de Janeiro, Brazil: Thunnus atlanticus (Lesson), Thunnus albacares (Bonnaterre) and Thunnus obesus (Lowe). Pairs of D. philobranchiarca were found on gill arches of T. albacares and T. obesus, in longitudinal rows of yellow cysts located inside grooves in the hard denticle palate (new site) of the three hosts species studied, and as disperse groups of cysts in the operculum (new site) and gill arches of $\mathrm{T}$. atlanticus (new host record). D. palati occurred as disperse groups of encysted worm pairs in the gill arches of T. albacares and T. obesus and in gill arches and operculum of $\mathrm{T}$. atlanticus (new host record). The pathological alterations induced by $\mathrm{D}$. philobranchiarca in the palate of $\mathrm{T}$. atlanticus are described for the first time. Original measurements and figures are presented.

Key words: Didymosulcus palati - Didymosulcus philobranchiarca - Didymozoidae - Thunnus spp. - pathological alterations

Three species of Scombridae from the coast of Rio de Janeiro were found to be parasitized with two different Didymozoidae species. Thunnus atlanticus (Lesson) is an epipelagic and small tuna, restricted to the Western Atlantic Ocean, which is commonly known as blackfin tuna and as "albacorinha" in Brazil. Thunnus albacares (Bonnaterre) is found worldwide in tropical and subtropical seas, above and below the thermocline, but is absent from the Mediterranean Sea, and is known as yellowfin tuna and as "albacora de lage" in Brazil. Thunnus obesus (Lowe) an epipelagic and mesopelagic species present in oceanic waters, occurs from the surface to a depth of about $250 \mathrm{~m}$, and is found worldwide in tropical and subtropical waters of the Atlantic, Indian and Pacific Oceans, but is absent from the Mediterranean Sea; the species is commonly known as big eye tuna and as "albacora bandolim" in Brazil. These tuna species feed on a wide variety of fishes, crustaceans and cephalopods.

Trematodes of the family Didymozoidae are parasites of marine fishes mainly belonging to the families Scombridae, Exocoetidae, Serranidae and Sphyraenidae, found predominantly in tropical and subtropical waters (Nikolaeva 1985). The occurrence of Didymosulcus palati (Yamaguti 1970) Pozdnyakov (1990) originally described in the Pacific Ocean, and of Didymosulcus philobranchiarca (Yamaguti 1970) Pozdnyakov (1990) found in the Pacific and Indian Oceans, is reported for the first time in Brazil, representing the first record of

Financial support: $\mathrm{CNPq}$

+ Corresponding author: marciajusto@ioc.fiocruz.br

Received 28 November 2007

Accepted 12 March 2008 this species in South America and in a new host. Pathological alterations induced in T. atlanticus by $D$. philobranchiarca are also described for the first time.

\section{MATERIALS AND METHODS}

Forty five $T$. atlanticus $(45-82 \mathrm{~cm}$ total body length; $1.3-6.0 \mathrm{~kg}$ ), $35 \mathrm{~T}$. obesus (42-80 $\mathrm{cm}$ total body length; $1.2-8.0 \mathrm{~kg}$ ) and $38 \mathrm{~T}$. albacares $(38-80 \mathrm{~cm}$ total body length; 0.55-7.8 kg), were examined from January 2004 to April 2007. The fishes were obtained from the Atlantic Ocean, off Cabo Frio, state of Rio de Janeiro, Brazil (22 $\left.52^{\prime} 46^{\prime \prime} \mathrm{S}, 42^{\circ} 01^{\prime} 07^{\prime} \mathrm{W}\right)$. Samples of palate containing encysted worms were fixed in formalin $10 \%$ for pathology. For identification, the parasites were released from dissected cysts and fixed in AFA (alcohol, formalin, acetic acid), stained in alcoholic-acid carmine, dehydrated in alcohol series, cleared in methyl salicilate and mounted in Canada balsam. Measurements are in micrometers, with the mean in parentheses followed by the number of specimens measured in brackets. For the pathological studies, fragments of the mucous palate and operculum of $T$. atlanticus containing cysts of $D$. philobranchiarca were removed, immediately fixed in $10 \%$ formalin and sent to the Laboratório de Patologia da Universidade Federal Fluminense, Niterói, Rio de Janeiro, Brazil. The material was then routinely processed for paraffin embedding and stained with hematoxylin and eosin (HE). Ecological terminology follows Bush et al. (1997). Statistical significance level was evaluated at $\mathrm{p} \leq 0.05$. Photographs were taken using Sony digital camera. Light micrographs were taken with a digital camera connected to Nikon Eclipse E 800 microscope. The studied specimens are deposited in the Helminthological Collection of Instituto Oswaldo Cruz (CHIOC), Rio de Janeiro, Brazil. 


\section{RESULTS}

D. philobranchiarca was found in longitudinal rows of yellow cysts (Fig. 1) located inside grooves in the hard denticle palate of the three hosts species studied and as disperse groups of cysts in the operculum and gill arches of $T$. atlanticus (new host record) and in gill arches of $T$. obesus. The cysts containing two identical specimens were covered with a thin, hard and transparent material. This parasite was detected in 17 of 35 T. obesus specimens examined, in 15 of 38 T. albacares specimens, and in 20 of 45 specimens of the new host T. atlanticus (Table). D. palati occurred as disperse groups of encysted worm pairs in the gill arches of $T$. albacares and T. obesus and in gill arches and operculum of $T$. atlanticus (new host record). This species was identified in 4 of 38 specimens of the type host $T$. albacares, in 8 of 35 T. obesus specimens, and in 5 out of 45 T. atlanticus specimens (Table).

Since the morphology of $D$. philobranchiarca and $D$. palati has been well described by Yamaguti (1970), we only present a brief description including the main findings.

\section{D. philobranchiarca (Yamaguti 1970) Pozdnyakov,} (1990) (Figs 1, 2)

Voucher specimens deposited: CHIOC n: 36934; 36935; 36936 a-c; 36937 a-c; 36938, 36939; 36940 a-b; 36941.

Measurements of 13 adult specimens: forebody 400800 (590) $[\mathrm{n}=9$ ] by 60-100 (80) [n =9] largest width; hindbody $2,000-4,700(3,300)[\mathrm{n}=13]$ long by 400-900 (700) $[\mathrm{n}=13]$ wide, comma-shaped, furrowed longitudinally with two distinct anterior lobes; mouth terminal, oral sucker pyriform 25-45 (35) $[\mathrm{n}=6]$ long by 15-35 (22) $[n=6]$ wide; esophagus simple; caeca narrow in forebody, tubular in hindbody reaching to near posterior extremity. Testes sausage-shaped slightly curved, 500-800 (600) [n=6] long by 50-140 (80) [n=9] wide;

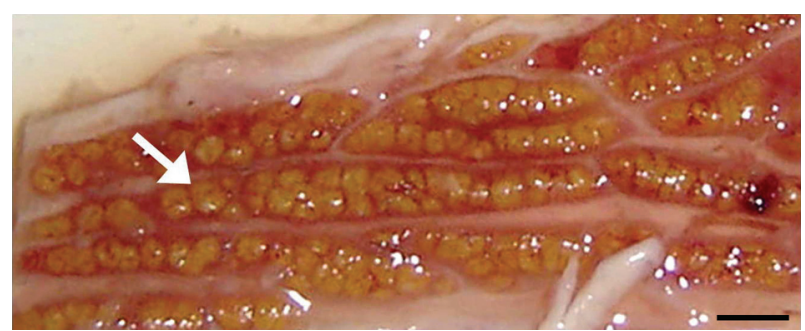

Fig. 1: cysts of Didymosulcus philobranchiarca (arrow) in the hard denticle palate of Thunnus atlanticus. Bar $=2.5 \mathrm{~mm}$. vas deferens running alongside metraterm in forebody and opening together, ventral to oral sucker. Ovary tubular divided into four branches, two anterior and two posterior. Seminal receptacle present. Vitelline gland with three main branches which bifurcates originating eight terminal branches. Uterine coils occupying most of available space of hindbody; eggs bean-shaped 15-17 (15) $[\mathrm{n}=13]$ by $10-12(10)[\mathrm{n}=13]$.

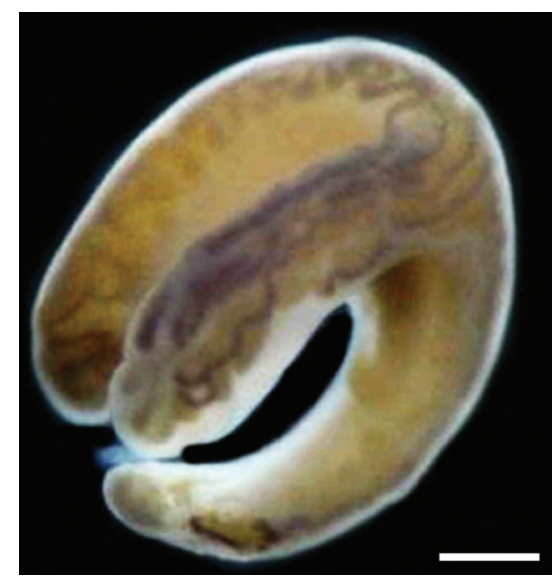

Fig. 2: photomicrography of D. philobranchiarca. Bar $=0.25 \mathrm{~mm}$.

\section{D. palati (Yamaguti 1970) Pozdnyakov (1990)}

(Fig. 3)

Voucher specimens deposited: CHIOC n: 36942; 36943 a-b; 36944; 36945; 36946 a-c; 36947; 36948; 36949 a-g.

Measurements based on 17 adult worms: forebody subcylindrical, flattened, 300-740 (460) [n=15] long by 50-110 (70) $[\mathrm{n}=15]$ wide attached to hindbody between two anterior lobes. Hindbody 1,400-2,700 $(1,900)[\mathrm{n}=17]$ long by $500-900$ (800) $[\mathrm{n}=17]$ wide, with two anterior lobes and median ventral furrow and posterior extremity curved ventrally. Oral sucker terminal 25- 40 (31) $[\mathrm{n}=12]$ long by $12-25$ (21) $[\mathrm{n}=12]$ wide; pharynx 15-22 (18) $[\mathrm{n}=9]$ in diameter; esophagus narrow; caeca narrow in forebody and inflated in hindbody, ending near posterior extremity. Testes sausage-shaped, 350-480 (410) $[\mathrm{n}=11]$ long by 50-130 (80) [n=7] wide; vas deferens running alongside metraterm; genital pore ventrolateral to oral sucker. Ovary divided in two tubular main branches 30-50 wide, uniting together at the front end

TABLE

Prevalence, mean intensity and mean abundance of Didymosulcus philobranchiarca and Didymosulcus palati from three hosts

\begin{tabular}{lccccccc}
\hline & \multicolumn{3}{c}{ D. philobranchiarca } & & \multicolumn{3}{c}{ D. palati } \\
\cline { 2 - 4 } & $\begin{array}{c}\text { Prevalence } \\
\text { Host }\end{array}$ & $\begin{array}{c}\text { Mean } \\
\text { intensity }\end{array}$ & $\begin{array}{c}\text { Mean } \\
\text { abundance }\end{array}$ & & $\begin{array}{c}\text { Prevalence } \\
(\%)\end{array}$ & $\begin{array}{c}\text { Mean } \\
\text { intensity }\end{array}$ & $\begin{array}{c}\text { Mean } \\
\text { abundance }\end{array}$ \\
\hline T. atlanticus & $44.4 \pm 15$ & $254.4 \pm 149.7$ & $113.1 \pm 73.9$ & & $13.3 \pm 10$ & $79.3 .4 \pm 109.9$ & $11.5 \pm 9.3$ \\
T. albacares & $39.5 \pm 16$ & $419.5 \pm 76.1$ & $165.6 \pm 121.8$ & & $10.5 \pm 10$ & $46.0 \pm 49.4$ & $4.8 \pm 5.5$ \\
T. obesus & $48.6 \pm 17$ & $143.7 \pm 121.7$ & $69.8 \pm 61.1$ & & $22.9 \pm 14$ & $50.3 \pm 30.2$ & $11.5 \pm 9.3$ \\
\hline
\end{tabular}




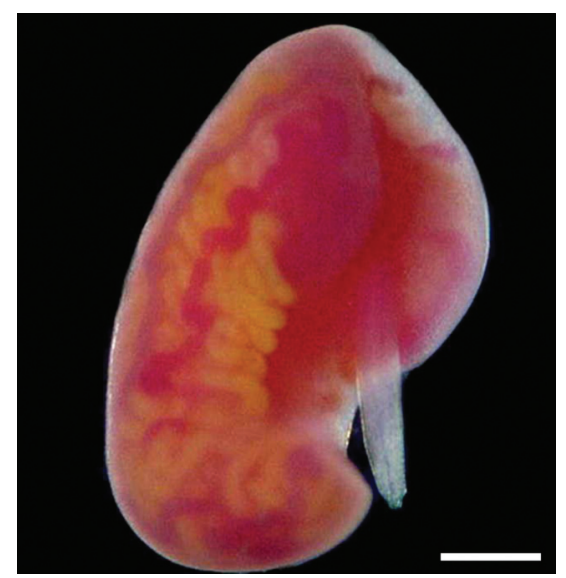

Fig. 3: photomicrography of Didymosulcus palati. Bar $=0.21 \mathrm{~mm}$.

near the base of anterior lobes; one of the main branches may present a short side branch. Seminal receptacle and shell gland present. Four vitellarian tubules undivided, 20-50 (30) [ $\mathrm{n}=17]$ wide, extending along convex side of hindbody, dorsal to ovary, reaching to posterior end of hindbody, one branch terminating short of posterior extremity. Uterus occupying all available space of hindbody, egg reservoir oval, eggs bean-shaped 15-17 (15) $[\mathrm{n}=17]$ long by 7-10 (10) $[\mathrm{n}=17]$ wide.

Pathological alterations induced by D. philobranchiarca in palate of T. atlanticus - Adult forms of $D$. philobranchiarca encysted in pairs in the mucous of denticulate palate of T. atlanticus were surrounded by bone laminae (Fig. 4); red blood cells and egg masses were frequently observed between the bone laminae and trematode tegument (Figs 6,7). The cysts were embedded in a highly vascularizated fibrous connective tissue adjacent to bone laminae and surrounded by a connective tissue capsule and red blood cells (Figs 4-6). This fibrous connective tissue was characterized by the presence of a mixed inflammatory infiltrate, circular hemorrhagic areas containing cholesterol clefts, and multiple egg masses surrounded by abundant brown-yellow pigment characteristic of melanomacrophage bodies and hemosiderin, observations suggesting parasitic migration (Figs 4,6). The eggs situated outside the parasites ranged from unstained to stained and contained acidophilic internal mass (Fig. 7).

\section{DISCUSSION}

Didymosulcus palati was first identified by Yamaguti (1970) in hard denticle palate and partly in the tooth plate of gill arches of T. albacares (=Neothunnus macropterus) from Hawaii, Pacific Ocean. In the present study, this species was found encysted in gill arches of the three host species studied and in the operculum of T. atlanticus (new host record) from Brazil, Atlantic Ocean, representing the first record of this species in South America. Our specimens are similar to the original description, differing only in few measurements: forebody width ranging from $50-110 \mu \mathrm{m}$ in our specimens and from $120-200 \mu \mathrm{m}$ in type-specimens; oral sucker measuring $12-15 \mu \mathrm{m}$ in our specimens and $21-93 \mu \mathrm{m}$ in the type-material. A side branch of the ovary branches as described by Yamaguti (1970) was only observed in one out of the 17 worms examined.
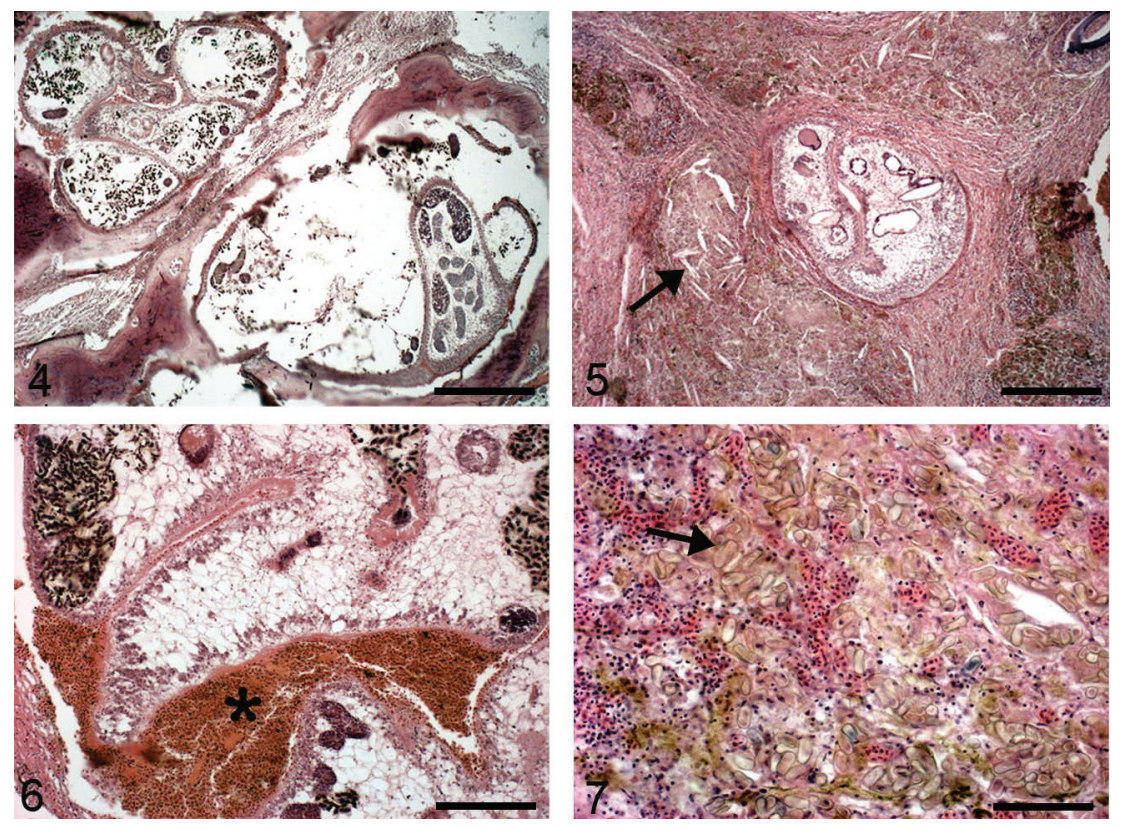

Figs 4-7: histological sections of the palate of Thunnus atlanticus with D. philobranchiarca. 4: pairs of parasites embedded in the bone tissue. HE. $\mathrm{Bar}=0.20 \mathrm{~mm}$; 5 : encysted parasites surrounded by a connective tissue capsule and embedded in the highly vascularizated fibrous connective tissue adjacent to bone laminae showing mixed inflammatory infiltrate and circular hemorrhagic areas containing cholesterol clefts (arrow) HE. Bar $=0.22 \mathrm{~mm} ; 6:$ D. philobranchiarca surrounded by red blood cells (asterisk). HE. Bar $=0.11 \mathrm{~mm} ; 7$ : eggs of $D$. philobranchiarca (arrow) embedded in the fibrous connective tissue highly vascularizated. These eggs were surrounded by abundant brown-yellow pigment, ranged from unstained to stained and contained acidophilic internal mass. HE. Bar $=0,06 \mathrm{~mm}$. 
D. philobranchiarca was originally described on gill arches of T. albacares (= Neothunnus macropterus) and T. obesus (= Parathunnus sibi) from Hawaii by Yamaguti (1970), in the genus Didymocystis and later transferred to Didymosulcus by Pozdnyakov (1990). This species was also reported in T. obesus and in Thunnus alalunga from Indian Ocean by Nikolaeva and Dubina (1985). In the present study, we found this species on the gill arches of T. albacares and T. obesus and in a new host, T. atlanticus, with the trematode parasitizing new sites, i.e., the palate of the three hosts species studied and the operculum of $T$. atlanticus.

The microscopic lesions associated with adult $D$. philobranchiarca trematodes and their eggs were severe and characterized by marked fibrosis, a chronic diffuse inflammatory process and hemorrhage. These results differed from those obtained by other investigators who reported that tissue infected with didymozoids usually presents little or even no tissue reaction or damage (Gibson et al. 1981, Karlsbakk 2001). Eiras and Rego (1987) and Pascual et al. (2006) also observed eggs masses, hemorrhages and lymphocyte infiltration in the connective tissue surrounding the parasitic nodules in the operculum of tuna fishes parasitized with didymozoids.

Kamegai (1971) reported the presence of a didymozoid species in the muscles of a marine fish in Japan and identified it as the adult worm of eggs found in human feces transmitted through fish consumption. According to this author, the presence of eggs of an unknown trematode species in human feces has been known in Japan since 1913. Chung and Cross (1975) found didymozoidlike eggs in stools samples of $41 \%$ of 158 school children from a Taiwan offshore island, wich were probably acquired by the consumption of marine fish. Carney et al. (1987) and Cross et al. (1989) found the eggs of didymozoids, among other helminths, in human feces from the Philippines. Recently, Pascual et al. (2006) described numerous ribbon-like aggregations of eggs of a didymozoid embedded in the musculature of the Atlantic mackerel Scomber scombrus L. These authors stated that among the largest, most numerous, and most diversified assembly of muscle-invading marine parasites are the free or encysted stages of didymozoid digenean trematodes and anisakid nematodes.

Heavy infections can reduce the commercial value of tuna fish, manly because of macroscopic alterations that make the flesh unappealing to eat (Lester 1979, 1980, Cribb \& Williams 1992, Pascual et al. 2006). Thompson (2000) recorded emerging zoonoses and allergies associated with the presence of helminth parasites in fish muscle, emphasizing the economic and public health importance of instituting control measures for edible seafood during inspections. In this respect, the increasing consumption of raw or uncooked fish in Brazil associated with the occurrence of these parasites in tuna fish may represent a risk factor of human infection.

\section{ACKNOWLEDGEMENTS}

To Instituto de Estudos do Mar Almirante Paulo Moreira, to Dr. Eliane Gonzalez Rodriguez, head of the Departamento de Oceanografia, for the facilities provided for examination of the fishes, to Dr. Eduardo Pimenta, Alice Berbert and Josué Martins Araújo for giving us the opportunity to obtain the fishes, to Mariana dos Santos Lopes for help both in the field and in the laboratory, and to Rodrigo Mexas, Laboratório de Imagens, Instituto Oswaldo Cruz for help with the preparation of the plates.

\section{REFERENCES}

Bush AO, Lafferty KD, Lotz JM, Shostak AW 1997. Parasitology meets ecology on its own terms: Margolis et al. revised. J Parasitol 83: 575-583.

Carney WP, Nocum R, Vergel AG, Pagaran I, Mercado A, Cross JH 1987. Intestinal parasites of man in Agusan del Norte, Philippines with emphasis on schistosomiasis and capillariasis. Philipp J Microbiol Infect Dis 16: 5-9.

Chung PR, Cross JH 1975. Prevalence of intestinal parasites in children on a Taiwan Offshore Island determined by the use of several diagnostic methods. J Formos Med Assoc 74: 411-418.

Cribb TH, Williams A 1992. Gonapodasmius williamsoni sp. n. (Digenea:Didymozoidae) from the pink snapper, Pagrus auratus (Teleostei:Sparidae) in Western Australia. J Proc Helminthol Soc Wash 59: 153-158.

Cross HJ, Zaraspe G, Alquizia L, Ranoa C 1989. Intestinal parasites in some patients seen at San Lazaro Hospital, Manila, Philippines. Philipp J Microbiol Infect Dis 18: 25-27.

Eiras JC, Rego AA 1987. The histopathology of Scomber japonicus infection by Nematobothium scombri (Trematoda: Didymozoidae) and of larval anisakid nematode infections in the liver of Pagrus pagrus. Mem Inst Oswaldo Cruz 82: 155-159.

Gibson DI, MacKenzie K, Cottes J 1981. Halvorsenius exilis gen. et sp. nov. a new didymozoid trematode from mackerel Scomber scombrus L. J Nat Hist 15: 917-929.

Kamegai S 1971. The determination of a generic name of flying fishes' muscle parasite, a didymozoid, whose ova have occasionally been found in human feces in Japan. J Parasitol 3: 170-176.

Karlsbakk E 2001. Didymozoid larvae (Trematoda) in the body musculature of cultured Atlantic herring larvae (Clupea harengus). Acta Parasitol 46: 164-170.

Lester RJG 1979. Descriptions of two new didymozoids from Australian fishes. J Parasitol 65: 904-908.

Lester RJG 1980. Host-parasite relations in some didymozoid trematodes. J Parasitol 66: 527-531.

Nikolaeva VM 1985. Trematodes Didymozoidae fauna, distribution and biology. In WJ Hargis, Parasitology and pathology of marine organisms of the World Ocean, NOAA, USA, p. 67-72.

Nikolaeva VM, Dubina VR 1985. On the Didymozoidae of fish in the western Indian Ocean "Concerning fauna Didymozoidae fishes from Western part of the Indian Ocean". Ekol Morya 20: 13-26.

Pascual S, Abollo EC, Azevedo C 2006. Host-parasite interaction of a muscle-infecting didymozoid in the Atlantic mackerel Scomber scombrus L. ICES J Mar Sci 63: 169-175.

Pozdnyakov SE 1990. Revision of the genus Didymocystis and validation of the genusDidymosulcus gen.n.(Trematoda:Didymozoidae). Zool Zhurnal 69: 5-11.

Thompson RCA 2000. Emerging parasite zoonoses. Int J Parasitol 30: 12-13.

Yamaguti S 1970. Digenetic Trematodes of Hawaiian fishes, Keigaku Publ. Co., Tokio, 426 pp. 